\title{
Review of Risk and Social Change in an African Rural Economy: Livelihoods in Pastoralist Communities by John G McPeak, Peter D Little and Cheryl R Doss
}

\author{
Mark Moritz
}

Correspondence: mark.moritz@ gmail.com

Department of Anthropology, The Ohio State University, Columbus, Ohio, USA

\section{Book details}

McPeak, JG; Little, PD; and Doss, CR

Risk and Social Change in an African Rural Economy: Livelihoods in Pastoralist

Communities.

London: Routledge; 2011.

224 pages, ISBN-10 0415615984, ISBN-13 978-0415615983

Keywords: Pastoral systems, Development, Risk, Rural livelihoods, Africa

\section{Review}

Pastoralism remains a viable production system for households and communities in the arid and semi-arid lands of Kenya and Ethiopia. That is one of the core messages of the book Risk and Social Change in an African Rural Economy, which is based on longitudinal and interdisciplinary research conducted within the framework of the Pastoral Risk Management Project (PARIMA). The PARIMA project examined changes in the rural economy of arid and semi-arid lands in Kenya and Ethiopia. The project served as an umbrella for multiple studies that led to an impressive number of MA theses, PhD dissertations, working papers and journal articles (which are all listed in the appendix). The book Risk and Social Change in an African Rural Economy offers a comprehensive review of the PARIMA project and a synthesis of its findings.

The PARIMA project ran from 1997 to 2006, encompassing periods of drought and recovery, and it offers great insight in how rural economies and pastoral communities have changed in the last two decades and how pastoralists cope with climate and market risks. While the project team included researchers from a wide range of disciplines - anthropology, animal science, economics, geography and range science - the emphasis is on economics, in particular, the integration of rural households in the regional economy. Two of the authors of the book are economists (McPeak and Doss), and one is an anthropologist (Little); the members of the team have been conducting fieldwork with pastoralists in East Africa for decades. Their disciplinary training and research experience has shaped the focus of the book. Pastoral systems cannot be described and explained solely in terms of adaptation to the environment. Pastoralists 
have been integrated in the larger market economy for long, and this thoroughly affects their household livelihood strategies. How pastoral households shape and are shaped by the regional economies that link them to national and international markets is the subject of this book. The book describes not only how pastoralists are diversifying their livelihoods, but also how pastoral production remains central to rural households and the regional economy.

The book is divided in eight chapters with an introductory chapter that explains the study; a background chapter that describes the study sites; five chapters that describe markets, risks, livelihood strategies, households and development; and a concluding chapter with a discussion of practical implications of this study for pastoral development. The book uses a comparative approach studying 11 communities in Kenya and Ethiopia that are part of a common marketshed in which goods and services flow from producers in rural areas to consumers in urban areas (as in a watershed). The analytical framework of the marketshed integrates the different units of analysis discussed in the chapters (e.g. markets, communities, households). The PARIMA researchers selected five sites in Ethiopia and six sites in Kenya that represent a wide range of cultural and ecological diversity, including seven main ethnic groups. By selecting communities, the researchers included not only 'pure pastoralists' who rely solely on pastoral production, but also pastoral households that have diversified their livelihood strategies and may no longer rely much on pastoral production. The result is a description of pastoral communities that emphasises the dynamics of how households adapt in different ways to changing circumstances.

The culture, history and political ecology of the area and the study sites and how these communities are situated in relation to critical ecological zones in the region like the Lake Baringo-Bogoria Basin and Marsabit Mountain are discussed in detail in chapter two. Readers unfamiliar with the region will likely be lost in the details, save for the overarching and reoccurring theme of insecurity that is affecting pastoralists throughout the region. A quarter of households in the study had suffered significant livestock losses due to insecurity, and a number have suffered human losses. Surprisingly, the problem of insecurity is not even mentioned in the concluding chapter in which the development implications of the study are discussed.

Chapter five - Changing Livelihood Strategies - represents the core of the book and is based on survey data from 153 households in Ethiopia and 190 households in Kenya between 2000 and 2002. Preliminary analysis of the data showed that two sources are critical for household security: access to livestock and participation in the cash economy (and that these are related; households with greater access to livestock also participate more in the cash economy). The authors divide their sample in four livelihood clusters (each with $25 \%$ of the sample) based on whether households were below or above the median of cash income and the median of livestock ownership. The description of the clusters shows how livelihood strategies have changed: households in the 'left out' livelihood group are low in both cash income and livestock assets; households in the 'moving from' (MF) group are high in cash income and low in livestock assets; households in the 'staying with' group are low in cash income and high in livestock assets; and households in the 'combining' group are high in both cash income and livestock assets. Each of the livelihood groups is illustrated by short descriptions of typical households that give insight into how households try to achieve economic security. In 
fact, it is only in chapter five, halfway the book, that the people in the study are represented by stories of individual pastoralists and their families. As an anthropologist, I would like to have seen more narrative descriptions of the livelihood strategies of individual pastoralists and how they cope with the risks of climate, markets and insecurity.

The authors describe in great detail the sources of income, access to livestock, sources of cash, expenditures and marketing of pastoral products and thus provide great insight into the different livelihood strategies that pastoral households pursue in search of economic security. One of the main findings is that there is considerable inequality, even though there are no major differences in terms of the livelihood diversification between poorer and wealthier households. The main difference between the poor and wealthy is that the latter get much greater returns from the same activities. As a result, households with more cash can spend more on education and healthcare, which increases the value of their human capital and further increases inequality within these rural communities. The findings suggest that the economy of scale may play a role and that there may be a threshold effect, which means that households with fewer livestock and less cash income are unlikely to overcome poverty. The question is whether households in the "moving from" group, some of which are under this threshold, will be able to achieve sustainable livelihoods using a combination of cash and pastoral income.

Researchers found that a large percentage of the households in the survey were selfidentified female-headed households, about 30\%, and they could be found in all four livelihood clusters. Moreover, in each of the clusters, women owned livestock, including camels, cattle and small stock, and women were involved in the herding activities. These findings challenge traditional images of men in charge of the herd and women in charge of the household, which no longer accurately describe the reality of pastoral households in the arid and semi-arid lands of Kenya and Ethiopia.

The book is part of the Routledge ISS Studies in Rural Livelihoods series, which focuses on studies that combine rigorous empirical studies with theoretically stimulating approaches and are accessible for policy practitioners. Throughout the book, but specifically in the conclusion, authors make explicit what the practical lessons of their study are for development of the rural economy. Most importantly, the authors argue that livestock and pastoral production are central for households in the area, including those households that are low in livestock assets. Pastoral production is not only important in terms of milk production (for subsistence and cash), but also in terms of livestock sales (for cash). The authors argue that development initiatives should build on the pastoral production system and link rural households to the markets. Pastoralists have not to be convinced of the value of diversification and education, but the challenge will be to integrate these with the pastoral production system in terms of allocation of land and labour. For example - how to deal with conflicts between agricultural and pastoral uses of the same natural resources or how to send children to school while maintaining mobility of the herds.

Most importantly, the authors argue, pastoralists should be integrated in the design of development project and address the needs of the target population. The PARIMA research project was designed to pay more attention to what pastoralists wanted in terms of development, but rather than using participatory methods, the teams used structured and semi-structured interviews to examine whether there was a strong 
consensus among informants, which may be indicative of community preferences. The results of these interviews show that pastoralists' development needs are basic human needs (e.g. access to water, education and human health) followed by pastoral needs (livestock health and marketing). Overall, this is a very useful and insightful book for researchers and policymakers. The main message is that pastoralism remains a viable production system for households and communities in the arid and semi-arid lands in Kenya and Ethiopia and that those development interventions should be built on pastoral livelihoods.

Finally, one of the commendable things of the PARIMA project is that it has made the data available through a website (http://dyson.cornell.edu/special_programs/AFSNRM/ Parima/index.htm) where anyone can download the data and codebook. The website provides instructions on how to use and cite the database.

Competing interests

The author declares that he has no competing interests.

Received: 20 September 2012 Accepted: 21 September 2012

Published: 14 November 2012

doi:10.1186/2041-7136-2-24

Cite this article as: Moritz: Review of Risk and Social Change in an African Rural Economy: Livelihoods in Pastoralist Communities by John G McPeak, Peter D Little and Cheryl R Doss. Pastoralism: Research, Policy and Practice 2012

$2: 24$

Submit your manuscript to a SpringerOpen ${ }^{\circ}$ journal and benefit from:

- Convenient online submission

- Rigorous peer review

- Immediate publication on acceptance

- Open access: articles freely available online

- High visibility within the field

- Retaining the copyright to your article

Submit your next manuscript at $>$ springeropen.com 